\title{
Black British North American Sailors in the Civil War
}

\section{Richard Reid}

\begin{abstract}
Pendant la guerre civile américaine, presque trois cents cinquante jeunes hommes de couleur venant des cinq colonies qui composaient l'Amérique du Nord britannique se sont portés volontaires dans la marine de l'Union. Cet article examine leur participation dans la guerre pour comprendre leurs identités sociales et leurs motivations pour s'enrôler. Une discussion de qui étaient ces hommes, comment et où ils se sont enrôlés, et l'autonomie qu'ils ont démontrée en choisissant leur service non seulement parle à la nature des communautés noires en Amérique du Nord britannique mais également à la nature évolutive de la guerre navale.
\end{abstract}

On 16 May 1861, just one month after the fall of Fort Sumter and the start of the American Civil War, John Anderson, a twenty-one year old "mulatto" from Nova Scotia, enlisted in the Union navy at a rendezvous station in New York City. Although Anderson gave his occupation as "none," he was rated as "ordinary seaman" indicating that he had extensive previous maritime experience. He signed on for three years although there is no record of the ship or ships on which he served. ${ }^{1}$ Indeed little more is known of John Anderson but then that is not remarkable. Very little is known or has been written of the hundreds of blacks from British North America who served in the Union navy during the Civil War. The best general or regional studies of Canadian involvement in the Civil War, such as Robin Winks' Canada and the United States: The Civil War Years or Greg Marquis' In Armageddon's Shadow, give little more than brief anecdotes of black involvement in the war, especially in the naval war. ${ }^{2}$ None attempt, in any systematic way, to measure the number of men who volunteered. This article begins to outline how extensive was the involvement of black sailors who left their various provinces to fight in the Union navy. A discussion of who these men were, how and where they joined, and the personal control that they displayed in selecting their service not only speaks to the nature of the black communities in British North America but also to the changing nature of the naval war.

1 This information is drawn from the entry for John Anderson is available at http://www.itd.nps.gov/cwaa/.

2 Robin Winks, Canada and the United States: The Civil War Years (Montreal, 1998), 198-9; Greg Marquis, In Armageddon's Shadow: The Civil War and Canada's Maritime Provinces (Montreal, 1998), 79-81, 109. Popular works also neglect the involvement of sailors in the war. See Claire Hoy, Canadians in the Civil War (Toronto, 2004), 124-5, 145

The Northern Mariner/le marin du nord, XXI No. 1, (January 2011), 1-26 
Of course, sailors from the British colonies, including black sailors, had been choosing to serve in the Union navy long before the Civil War broke out despite official attempts to ban the use of both black and foreign sailors. The United States Navy seldom had a sufficient number of suitable recruits, especially in years of prosperity, for there were other employers of mariners. In time of peace, the merchant marine paid higher wages and in time of conflict privateers ran fewer risks for shorter time with greater chance of rewards. Nevertheless, sailors frequently joined the peace-time navy, served an enlistment term and then hired out their services to a different employer. This was a common practice whether they were career or short-term sailors. ${ }^{3}$ One notable Nova Scotian, William Hall, provides one such an example. He was the son of black refugees who had come to the province during the War of 1812. His father was a sailor who worked at the ship-building yards at Half-Way River (Hantsport), and William followed his father's trade. After crewing on ships out of Half-Way River, he served in the American navy for some years in the late 1840s. He then chose not to re-enlist in that navy but rather joined the Royal Navy in 1852 as an able seaman. After twenty-four years of exceptional service, he retired at the rank of quartermaster and returned to Nova Scotia, a recognized hero. ${ }^{4}$ How many other Maritimers served in the American navy before the war is extremely difficult to determine but Hall's time in the navy was not unique among Maritime sailors. Maritime sailors were among the two-hundred-odd crew when the USS Levant, a U. S. Navy sloop on route from the Hawaiian Islands to Panama, went down in a hurricane in September $1860 .^{5}$

Almost as soon as the Civil War began, willing black volunteers, including men from British North America, began entering the Union navy. This was possible because the traditions and practices in the navy had long been very different from the army. Following the passage of the federal Militia Act of 1792, the army officially refused to enroll black soldiers and that prohibition lasted up to the Civil War. ${ }^{6}$ By contrast, the

3 Judith Fingard describes a career sailor as someone whose goal "was to ascend the seafaring hierarchy as rapidly as possible" while casual sailors, someone who signed sometimes repeatedly for short terms, included men for whom employment at sea was "either as an escape from the pressures of society or as a short-term prospect for adventure or employment." Enlistment records for the Civil War indicate that short-term sailors made up a significant number of the black enlistments. Judith Fingard, Jack in Port: Sailortowns of Eastern Canada (Toronto, 1982), 47-56.

4 Hall served in the Crimean War and later, during the Indian Mutiny, he was part of a naval brigade sent to the relief of Lucknow. For his part in the fighting around the city, Hall was awarded the Victoria Cross in 1859, "the first black, the first Nova Scotian, and the first Canadian sailor to receive the decoration." Bridglal Pachai, Dictionary of Canadian Biography, http://www.biographi.ca/009004-119.01-e.php?BioId=40882.

5 Although the fate of the ship was never known, ten months later a small bottle containing a card was recovered on Sable Island, Nova Scotia, that seemed to contain a message from the last of the crew. Thomas Willett of Pubnico, Nova Scotia, whose son had been on the Levant, was given the card. Yarmouth Herald, 30 January 1862 (courtesy Yarmouth County Museum and Archives).

6 In times of national crisis, of course, the law was sometimes ignored. While the Battalion of 
navy had a long tradition, starting from the American Revolution, not only of employing black sailors but also of racially integrating them in all of its vessels. As far back as the American Revolution, black crewmen served on American warships. In the ensuing years and despite official concerns, the navy continued to rely on black sailors in times of crisis, including some slaves enlisted by their owners who then collected their wages. ${ }^{7}$ Very early on, the navy had tried to prohibit the enlistment of both black and foreign sailors but that proved impractical. In August 1798, Secretary of the Navy Benjamin Stoddard had issued orders blocking the recruitment of black crewmen in the navy. ${ }^{8}$ Nevertheless, the chronic shortage of experienced sailors made strict enforcement almost impossible. In 1807, in the aftermath of the Chesapeake incident, Congress banned the enlistment of foreign nationals but allowed, officially for the first time, the enlistment of free African Americans. ${ }^{9}$ Although in 1813 Congress repeated the ban on aliens enlisting, immigrants in large numbers continued to enter the navy and they included some black sailors. ${ }^{10}$ In 1828, Secretary of the Navy John Branch complained that foreign seamen were "a distinct class of people from those useful citizens who have sought protection under our institutions...very few of them have their interests located here, or are bound to us by one of the all the ties which connect a man with his country." 11 Regulations barring foreign sailors, however, could be evaded by purchasing fraudulent certificates of citizenship, often for as little as fifty cents. In addition, American recruiters often assigned "purser's names," Anglicized versions of their proper names, to foreign sailors, making it difficult to estimate the number of foreigners in the service. ${ }^{12}$ In any time of necessity, needs trumped theory. In 1861, Secretary of the Navy Gideon Welles told members of the House of Representatives that, because of the need for sailors, the law banning foreign enlistment had "not been rigidly observed" but they tried to enlist only experienced sailors. ${ }^{13}$

Despite an equal reluctance to enlist African Americans, naval records show that

Free Men of Color who served under General Andrew Jackson at New Orleans in 1814 did so under that state's special exemption, there is evidence of black soldiers serving in some regiments in dire need of manpower, including the $26^{\text {th }}$ United States Infantry Regiment.

7 Steven J. Ramold, Slaves, Sailors, Citizens: African Americans in the Union Navy (Dekalb, 2002), 8, 16.

8 David L. Valuska, The African-American in the Union Navy: 1861-1865 (New York, 1993), 10.

9 Rambold, Slaves, Sailors, Citizens, 21.

10 Michael J. Bennett, Union Jacks: Yankee Sailors in the Civil War (Chapel Hill, 2004), 9.

11 James E. Valle, Rocks \& Shoals: Order and Discipline in the Old Navy 1880-1861 (Annapolis, 1980), 19.

12 During the Civil War, while the largest block of foreign black soldiers came from the Caribbean islands followed by British North America, there were representatives from many countries in Africa and Asia. While only some of the fifty-eight sailors from Cape Verde Islands had Anglicized names, all of the eight sailors from India, Ceylon, and Borneo had "American" names.

13 Robert M. Browning, From Cape Charles to Cape Fear: The North Atlantic Blockading Squadron during the Civil War (Tuscaloosa, 1993), 202. 
black sailors saw action during the Quasi-War with France, the campaigns against the Barbary States, the War of 1812, and the Mexican War. ${ }^{14}$ In 1816, black crewmen made up about fifteen percent of the crew of the frigate USS Java. ${ }^{15}$ Nevertheless, in 1839, as a result of the serious recession created by the panic of 1837, Isaac Toucey, acting secretary of the navy, capped black recruitment at five percent of monthly recruiting totals and banned the practice of slaveholders enlisting their slaves and receiving the wages. The quota had a significant impact on black volunteering and by 1861 the percentage of blacks on Federal warships had fallen under three percent. ${ }^{16}$

Although the total number of Civil War enlistments in the Union navy can be precisely identified, 118,044 enlistments, the exact number of black sailors who served through the Civil War era is much more difficult to establish. The navy, unlike the army, did not record a recruit's racial identity. As a result, researchers trying to identify sailors of African ancestry are forced to use the physical descriptions normally included on the enlistment forms. Sailors listed on the forms as "black," "negro," "colored," "nigger," or mulatto" can be identified with greater certainty than recruits described as "dark," "yellow," or "brown." Even after cross tabulating a range of naval documents over the career of a recruit, the racial identity of a sailor may not be absolutely established

As a result, we will probably never know exactly how many of the Union sailors who enlisted during in the Civil War were black, much less how many came from British North America. The first rough estimate of the number of black sailors who served in the Civil War was made early in 1902 by the secretary of the navy in response to a Congressional request. Senior officers who were veterans of the war remembered blacks making up a quarter of the total numbers so the secretary divided the total enlistment by four and reached the number of 29,511 black sailors. ${ }^{17}$ Decades later, David L. Valuska estimated black enlistment after a detailed examination of the records of the navy's various rendezvous stations for his monograph on black sailors. On the basis of his findings, he revised the total number of black sailors downward to 9596, or about eight percent of the total force. He also identified 110 men from British North America from among the foreign black sailors. ${ }^{18}$ His figures, while based on actual research and more systematic than earlier estimates, omitted the many sailors who enlisted on board naval vessels or whose enlistment records were missing. More recently, a special research partnership between Howard University, the Department of the Navy, and the National

14 Ramold, Slaves, Sailors, Citizens, 11-20.

15 Valle, Rocks \& Shoals, 20.

16 Ramold, Slaves, Sailors, Citizens, 16-23; Valuska, African-Americans in the Union Navy, 11.

17 Herbert Aptheker accepted and popularized this number after randomly checking the muster rolls for several ships serving in 1863 and 1864 . Those finding generally agreed with the official assessment. Herbert Aptheker, "The Negro in the Union Navy," Journal of Negro History XXXII (April 1947): 179.

18 He lists thirty from "Canada," eighty from Nova Scotia, and one from Cape Breton. No sailors are listed from New Brunswick or PEI. This research, done for his 1973 dissertation, was slightly modified for his monograph. Valuska, The African American in the Union Navy, $25,38,53,58,62,83-84$. 
Parks Service, headed by Joseph Reidy, has currently managed to identify nearly 18,000 black service men, including 348 black sailors born in British North America. ${ }^{19}$ The latter were part of the fifteen hundred foreign volunteers, with the largest block from the islands of the Caribbean, who joined the Union navy. Researchers working for the Civil War African American Sailors Project sifted through thousands of pages of enlistment records and quarterly muster rolls of navy vessels looking for descriptive terms assigned to the recruits that indicated African ancestry. ${ }^{20}$ While their findings are the most precise to date, extracting racial identity from records that ignore race will always be problematic and some black sailors have likely been missed. ${ }^{21}$ Indeed, Valuska includes the names of a number of sailors from British North America that are not identified as such by the Civil War Sailors Project. ${ }^{22}$ The omission of one well-known black Nova Scotia veteran by both studies suggests that even more men from British North America have been missed. Ben Jackson, a black sailor from Lockhartville, Nova Scotia who is reputed to have enlisted under the name Lewis Saunders, was wounded while serving as a gun captain in the USS Richmond. After his discharge he returned to his home province and settled in the Annapolis Valley. ${ }^{23}$ Neither the Civil War Sailors Project nor Valuska, however, have any record of either Lewis Saunders or Ben Jackson serving among the black sailors. How many other black British North American sailors have been missed remains unclear. ${ }^{24}$

19 For a full description of the project, see Joseph P. Reid, "Black Jack: African American Sailors in the Civil War," in William B. Cogar, ed., New Interpretations in Naval History: Selected Papers from the Twelfth Naval History Symposium (Annapolis, 1997), 213-220. The results of the project's research are available on-line at http://www.itd.nps.gov/cwss/. All general demographic and recruitment data for this chapter, unless otherwise indicated, is drawn from the Civil War Sailors Project. The information provided for most recruits includes place of birth, age, complexion (a signifier of race), occupation, height, place of enlistment, place of enlistment term of enlistment, and rating. For most sailors there is also a muster record listing dates and ships. As with virtually all Civil War records, there is a degree of error in the data.

20 Individuals recorded as "Negro," "Colored," or "Mulatto" were considered black sailors. Other cases, such as a person whose complexion is listed as "Yellow," presented more difficult problems of classification, especially since the navy was enlisting foreign sailors from many different areas. The project's stated policy was to err on the side of inclusion.

21 Despite any possible omissions, the Project's research provides the most complete data base that we have on black Civil War sailors. All general demographic and recruitment data plus individual sailor's service records used in this chapter, unless otherwise indicated, is drawn from the Civil War Sailors Project.

22 In a few cases, the differences may simply be confusion over the spelling of a name, as in the case of Berry Chever or Cheves. In most cases, Valuska identifies men not identified in the Civil War Sailors Project. Examples of the men missed by the larger project are Adams Willis from "Canada," Edward Berrion from Halifax, and William A. Dehart from Nova Scotia. Valuska, African Americans in the Union Navy, 122, 125, 126, 313.

23 Greg Marquis, In Armageddon's Shadow, 80-81.

24 For this study, the arbitrary but methodologically useful definition of who are to be counted as British North Americans is based on nativity rather than self-identification. The naval records record place of birth. Young black men who moved to British North America in their 
At the outbreak of war, the navy, like the army and other branches of the government, was largely unprepared for the type of conflict that it would face in 1861 . The small pre-war navy had been primarily a "blue water" fleet tasked with protecting American commercial interests around the world and it had very limited resources in terms of both men and ships. In the spring of 1861, many of the ships that the navy had on its books were laid up or unserviceable. Only thirty-nine were commissioned and in service and all but twelve were posted in foreign stations in Asia, South America and Africa. $^{25}$ Moreover, Isaac Toucey, secretary of the navy during the secession crisis, refused to recall some of these ships to American waters lest it be seen as an act of aggression against the South. ${ }^{26}$ Thus, President Lincoln found out from his secretary of the navy, Gideon Welles, in late March 1861 that he had only a dozen vessels at his immediate disposal to cover all of the Gulf of Mexico and the Atlantic. ${ }^{27}$

Despite what is sometimes argued, the navy, on the eve of the war, was beginning the process of modernization. The United States Naval Academy had been established in 1850 in part to professionalize the officer class. ${ }^{28}$ Driven in part by European examples, the navy understood the need to change from sail to steam and had begun that transition. After experimenting with paddle wheel warships, the navy decided that propeller-driven vessels were more efficient and their engines less vulnerable to enemy fire although the paddle wheel vessels would remain an important part of the Civil War navy. During the 1850s, six large screw frigates plus a number of steam sloops were built that compared favorably with similar vessels in any European fleet. ${ }^{29}$ These ships, however, were essentially unarmored sailing ships with an auxiliary propulsion system to

early years are thus missed, nor is it clear how many of them would have identified themselves as British North Americans. Anecdotal evidence indicates that some served in the navy. Tom Henson, the son of Josiah Henson, a well known black abolitionist and minister who had escaped to Upper Canada in the 1830s, joined the navy and his family lost track of him. Joseph Hayden, who had escaped from Kentucky as a child and lived for a while in Canada West, enlisted and served in the Gulf Coast Squadron before his death in 1865. Fergus M. Bordewich, Bound for Canaan: The Epic Story of the Underground Railroad, America's First Civil Rights Movement (New York, 2005), 431.

25 In addition to the twelve attached to the Home Squadron, six were in the East Indies Squadron, three in the Mediterranean Squadron, three in the Brazilian Squadron, eight in the African Squadron and seven in the Pacific Squadron. Gary D. Joiner, Mr. Lincoln's Brown Water Navy: The Mississippi Squadron (New York, 2007), 4. Paul Silverstone, however, claims that in March, 1861, there were forty-two ships in commission. Paul H. Silverstone, Civil War Navies, 1855-1883 (Annapolis, 2001), ix.

26 As soon as Lincoln took office, Congress voted censure against Toucey. William M. Fowler, Jr., Under Two Flags: The American Navy in the Civil War (New York, 1990), 34.

27 Dean B. Mahin, One War at a Time: The International Dimensions of the American Civil War (Washington, 1999), 45.

28 A naval academy was actually established in 1845, then reorganized and given its current name in 1850. For more on the establishment of the academy, see Mark C. Hunter, A Society of Gentlemen: Midshipmen at the U.S. Naval Academy, 1845-1861 (Annapolis, 2010). 
be used at such times as necessary. Marine engines were occasionally unreliable, coal was expensive and wind was free. As a result, these naval vessels still required a large complement of experienced seamen to serve and sail them. These were the warships expected to protect the wide-spread Northern merchant marine from possible Southern privateers and Confederate raiders.

The navy had another problem that quickly became evident when the war started. Except for its auxiliary craft, none of the ships in service were suitable for use on America's river system or close in work on the coastal estuaries. Indeed, Southern senators had ensured that the draft of the new vessels the navy was building were too deep for effective use in most Southern harbors or rivers. ${ }^{30}$ Successful prosecution of the Civil War, however, would require blockading fleets capable of operating close in to shore, often under fire from enemy batteries, in order to seal the more than three thousand miles of Southern coastline and all of its ports and river mouths. In addition, the navy quickly realized that it had to develop a military capacity to control the inland waterways in support of the army. All this would demand a dramatic expansion of the navy's size and capacities. It would mean different kinds of ships and a desperate need for new recruits. While the existing frigates and sloops, vessels such as the USS Minnesota or the USS Hartford, would always require a crew of experienced mariners, the application of steam and armor in the navy's newly created "brown water" fleet on the inland rivers allowed for a deskilling of servicemen. ${ }^{31}$ The creation of a fresh water fleet especially brought the navy into contact with escaping slaves or "contrabands." 32 Given the chronic shortage of crewmen and the eagerness of Southern blacks to serve, Gideon Welles soon authorized navy recruiters to tap this pool of labor, as long as they were enlisted at the rating of "boy," a restriction that he removed in December 1862. 33 Both parts of the new navy would offer opportunities for men from the British colonies. Driven by the urgent need for more sea power, the navy dramatically expanded the size of its fleet, purchasing or chartering merchant ships while speeding up the construction of new warships. By the start of July 1861, the navy had eighty-two vessels commissioned

30 Joiner, Mr. Lincoln's Brown Water Navy, 3.

31 Although Admiral David G. Farragut had used both the Hartford and the Brooklyn to force his way passed the forts guarding New Orleans and took them as far as Vicksburg, he had serious misgivings about using them on the Mississippi. Fowler, Under Two Flags, 116-22, 129-30, 193, 219.

32 The term was first used by General Benjamin Butler in May 1861. Three Virginian slaves had escaped to Union lines only to have their owner, a Confederate officer, arrived the next day under a flag of truce and demanded the slaves be returned, citing the Fugitive Slave law. Butler avoided a legal dilemma by declaring the slaves "contraband of war" and, as confiscated property of a belligerent, not liable for return. Soon all escaped slaves were referred to as contrabands.

33 The lowest rating in the Union navy, based on the combined factor of age and skills, was "boy," first, second, or third class. Before the war, this rating was designated for recruits less than eighteen years of age. All ex-slaves, regardless of age, were initially rated boy. The ranking, placing them at the bottom of the naval hierarchy, fed racial stereotypes and limited the ex-slaves to the lowest pay rate. Bennett, Union Jacks, 163-64. 
and by the end of the year the figure had grown to 264. A year later the number had reached 427 and by the end of the war the navy had almost seven hundred ships of every kind. The annual naval expenditures over the same time kept pace with the expansion of the fleet, swelling from $\$ 12$ million to $\$ 123$ million. $^{34}$

If these new ships were to be used effectively, the navy needed thousands of new recruits and it had to compete with an army clamoring for men. The navy had only 7,600 seamen in uniform when the war began and while few sailors opted to leave and serve the South, unlike the officers, of whom one fifth resigned their commissions to join the Confederacy, their numbers were woefully inadequate. ${ }^{35}$ Lincoln immediately authorized an expansion of an additional 18,000 seamen but, given the competition with the army for men, it was not clear where they would get them. The urgent need to expand the naval roster and the voracious need of the army for white volunteers forced the navy increasingly to utilize black sailors, whether they were Southern contrabands, Northern blacks, or volunteers from foreign countries. While precise numbers are difficult to assess, the percentage of black sailors in the navy rose rapidly. As the war progressed, black sailors made up a larger and larger part of the naval personnel. By the end of May, 1861, after a burst of new enlistment, black seamen made up eight percent of the naval roster and that figure increased to a peak of approximately twenty-three percent in the fall of 1864 before slowly falling to around seventeen percent at the war's end. ${ }^{36}$ British North American born-sailors made up almost five percent of the black seamen in the Union navy. ${ }^{37}$ Although black seamen were more numerous as the war progressed, they were never a homogeneous group nor were they evenly distributed across the service. The actual percentage of black crewmen who made up the crew of any individual vessel varied enormously, both by theatre of service and types of vessel examined. About one in ten of the sailors in the European Squadron, hunting Confederate commerce raiders in the North Atlantic, were black. In the squadrons blockading the Southern coast, that number was one in four while in the fresh water fleet, blacks accounted for more than one third of the mariners. The nature and duties of naval vessels also influenced where blacks served. While there were only limited numbers on the frigates and sloops of war, black sailors were disproportionately represented on the barks and schooners that supplied and supported the active warships. ${ }^{38}$ For black British North Americans, this factor raises a range of questions about their background and motives, when and where they joined, in what theatre they served and how they were perceived by their white crewmates.

As the navy sought ways to expand its manpower, the pattern and growth of

34 David Herbert Donald, Jean H. Baker, and Michael F. Holt, The Civil War and Reconstruction (New York, 2001), 398.

35 James M. McPherson, Battle Cry of Freedom: The Civil War Era (New York, 1988), 313.

36 Joseph P. Reidy, "Black Men in Navy Blue during the Civil War," Prologue: Quarterly of the National Archives and Records Administration XXXIII (Fall 2001), 157-8.

37 Bennett puts the figure at 4.70 percent of all Union sailors. By contrast, British North Americans in the Union army made up only 2.6 percent of all soldiers. Bennett, Union Jacks, 10-11.

38 Reidy, "Black Men in Navy Blue," 158-9. 
general black enlistment was mirrored by that of the black volunteers from the British colonies. Slightly more black sailors entered the navy in 1862 than in 1861. Following the Emancipation Proclamation, barriers to black service, both physical and psychological, crumbled and black enlistment among African Americans increased in 1863 and surged in 1864. By January 1865, as the navy had achieved most of its objectives and as the war appeared to be reaching its end, the navy began cutting back its complement of sailors. ${ }^{39}$ Table 1 shows a pattern of enlistment that was quite similar for Canadian and Maritime sailors.

\begin{tabular}{|l|c|c|c|c|c|c|}
\hline & 1861 & 1862 & 1863 & 1864 & 1865 & Total \\
\hline Canada West $^{*}$ & 2 & 11 & 9 & 188 & 5 & 215 \\
\hline Canada East & - & - & 1 & 6 & - & 7 \\
\hline Nova Scotia & 10 & 15 & 14 & 31 & 3 & $74^{* *}$ \\
\hline New Brunswick & 6 & 4 & 7 & 29 & 3 & 49 \\
\hline PEI & - & - & - & 2 & 1 & 3 \\
\hline Total & 18 & 30 & 31 & 256 & 12 & $348^{* *}$ \\
\hline
\end{tabular}

\section{Table 1: Enlistment of Black British North American Sailors}

* All recruits who listed "Canada" as their place of birth are credited to Canada West except for the men who listed a Quebec city, such as Thomas Bryant who gave "Quebec, Canada" as his place of birth. As a result, a few sailors born in Canada East may have been credited to Canada West. This decision may also capture a few Maritimers, men such as John Littlefield who gave "Cape Breton, Canada," as his place of birth.

**One sailor born in Nova Scotia, William Maxwell, has no date or place of enlistment on his records.

In 1862, thirty black sailors from BNA joined the navy and thirty-one more enlisted the following year. 1864 saw that number swell to 255, primarily made up of a large number of recruits from Canada West. This enlistment coincided with a change in regulations allowing bounties, previously only offered to soldiers, to be paid to enlisting sailors and crediting these recruits to a district's draft quota. ${ }^{40}$ The Enrollment Act of 1863 had established a national draft to fill the army's ranks but the act excluded the navy. Federal bounties, supplemented by many communities, had been paid to soldiers almost from the start of the war but sailors had not been eligible for the money. The Amendatory Act of February 1864 ended the inequity. New sailors could now receive federal bounties and because they were now credited towards their district's draft quota, local communities had greater reason to support naval enlistment. ${ }^{41}$ Although the

39 Ramold, Slaves, Sailors, Citizens, 56.

40 Previously, port towns had discouraged naval enlistment because these recruits were not counted towards the districts' draft quotas. In fact, these towns had provided bounties to 5,000 seamen to join the army. Ari Hoogenboom, Gustavus Vasa Fox of the Union Navy (Baltimore, 2008), 216; Ramold, Slaves, Sailors, Citizens, 66.

41 Some British North Americans, who were by occupation mariners but who had joined the army, took advantage of the act's provision that allowed trained seamen to transfer from the army to the navy. Since black regiments had just started to be formed in 1863, few black 
monetary incentives to join remained, in the last year of the war the number of enlisting black British North Americans dropped to only thirteen as the navy cut its manpower. Nevertheless, the sailors who joined in the last months of the war frequently served the peace-time navy well after the war was over. Men such as Abraham Bankster and Israel N. Dolman, both experienced seamen from Nova Scotia who crewed on the USS Hartford, served for years after the war's end in the Pacific Squadron. Two of the three sailors from Prince Edward Island, John H. Thompson and Charles H. Trust, enlisted together at Portsmouth, New Hampshire, near the end of 1864 and both joined the crew on the iron-hulled double-ender gunboat, USS Mohongo. In May 1865, they helped sail the gunboat through the Straits of Magellan during a severe gale to take up service with the Pacific Squadron. ${ }^{42}$

The first decision that sailors had to make, once they had decided to enlist, was for how long they wished to serve. During the war, enlisting sailors, unlike soldiers, could choose for how many years they wished to serve. They could select a term of service ranging from one to three years or even enlist specifically for the duration of the war, and many ex-slaves in the Mississippi Valley did just that. Steven Ramold argues that the length of the term selected by the recruits related to their perceptions of how long the war would last. In 1861, in the first year of what many people thought would be a short war, most of the recruits joined for three years while a year later, with enthusiasm for the war ebbing, many selected a one or two year term of service. The result was that by 1864 , the year that most black British North Americans enlisted, the Navy was trying to fill new warships while at the same time replace veteran seamen whose term of enlistment had expired. ${ }^{43}$ The choice of the British colonial sailors as to how long they wished to serve varied only slightly from American sailors. In 1861, two thirds of the men volunteering signed on for three year terms and of this group, more than half came in at the rank of landsman. ${ }^{44}$ In the next year, the sailors split between selecting a three year and a one year term of enlistment. Only one sailor chose two years, while for the first time, two sailors enlisted for the duration. In 1863, while the numbers of recruits from British North America remained steady, their choice of time to serve had altered. All but two of the sailors joining in that year signed on for only one year. The following year saw a turn about in both the number of men enlisting and their term of service. In 1864, 252 British North Americans entered the Navy and more than three quarters were from Canada West. Two hundred elected to serve three years while thirty seven signed on for one year and eighteen for two years. Only one man enlisted "for the war." The actions of these men were consistent with the behavior of other sailors from outside the United States. "More than half of foreign sailors enlisted in the last two years of the war," and

seamen in infantry regiments transferred. However, at least one man, William Martin of Pictou, Nova Scotia who transferred to the USS Minnesota, may have been a black seaman. On his files, the color of his eyes, hair and complexion are given as "black, black, dark." James W. Geary, We Need Men: The Union Draft in the Civil War (Dekalb, 1991), 12-13, 6667; http://www.tfoenander.com/minnesota.htm.

42 http://www.history.navy.mil/danfs/m13/mohongo.htm

43 Ramold, Slaves, Sailors, Citizens, 75-6.

44 A total of 18 colonists enlisted in 1861 and 39 in 1862. 
most joined at the port cities of the mid-Atlantic and New England. ${ }^{45}$ The following year, at a time when the Navy was cutting back its forces, only a dozen sailors from British North America enlisted and two thirds of these men selected to serve for three years.

John Anderson, the first black British North American to join the war-time Union navy, had given his occupation as "none" when he enlisted. Nevertheless, the recruiting officer had assigned him a rating of "ordinary seaman" so the Maritimer clearly had considerable experience on the water. All men enlisting in the navy were assessed and assigned a rating, rather than a rank, based on their experience and skills. The most experienced recruits, men with at least five years of maritime service, were rated "able seaman" and paid \$16 to \$18 a month. They handled the sails and riggings, steered the vessel and provided critical leadership throughout the ship. Men like Anderson who were rated as "ordinary seaman" generally had two years or more of maritime service and were paid $\$ 14$ per month. They manned the guns, operated the ship's boats and supervised the landsmen. Landsman, the most common rating in the Civil War navy regardless of race, were men with negligible naval experience who were expected to learn their skills on the job as the navy had no dedicated training facilities. They earned $\$ 12$ a month. When the war began, recruits who were under eighteen was rated as first, second, or third class "boy" with wages of $\$ 10, \$ 9$, or $\$ 8$ a month depending on their age and skills. They were expected to do light labor, serve the officers, carry ammunition during combat and handle any other tasks assigned them by the commander. ${ }^{46}$ When the navy began enlisting ex-slaves, these recruits, initially, could only sign on as boys. As the navy continued its transition to steam power, two other ratings became more common. Firemen (first and second class) looked after the boilers, kept watch on the steam pressure and, under direction, helped in the repair of the machinery. They made thirty or twenty-five dollars a month, depending on their classification, in line with their years of experience. ${ }^{47}$ Coal heavers, a job that paid $\$ 18$ per month, required little previous skill but great endurance. Using shovels and wheel barrows, the men made sure that the load of coal was evenly distributed in the bunkers and kept the boilers fed. It was heavy demanding work in extreme temperatures. ${ }^{48}$

Anderson's rating as ordinary seaman not only guaranteed him greater status, higher pay and more skilled tasks, but it also suggests that when he put "none" as his

45 Ramold, Slaves, Sailors, Citizens, 60.

46 Valuska, African Americans in the Union Navy, 31; Joseph P. Reidy, "Black Men in Navy Blue," 156. In 1864 the pay for most ratings was raised by two dollars a month. Ramold, Slaves, Sailors, Citizens, 85.

47 Given the length of time training on a steam powered vessel required for this rating, it is not surprising that only one black British North American enlisted with this rating. More surprising is the fact that the seaman, Samuel Smith, had given his occupation as a farmer in Canada West before he enlisted at Cincinnati in December 1862. Within a few weeks he was serving on the USS Silver Lake, a wooden stern-wheel gunboat attached to the Mississippi Squadron.

48 Among the British North American sailors, only one man, James Ingraham, a twenty-five year old Nova Scotian who ironically had claimed to be a fireman before the war, signed on as a coal heaver. 
occupation, he meant to indicate that he was unemployed and not that he was unskilled. It was likely that Anderson was between "berths" and this was probably also true of many other sailors who had entered "none" as their occupation, judging by how they were subsequently rated. ${ }^{49}$ Just two days after Anderson enlisted, John A. Johnson, a twentyone year old from St Johns, New Brunswick, signed on in Boston for one year. Johnson, who also listed his occupation as "none," was rated, like a majority of new recruits, as landsman. Exactly what factors led these two men to join the U.S. Navy is not clear but they seemed to fit the pattern of enlistment identified by Michael Bennett who argues that sailors, unlike soldiers, seldom enlisted for ideological reasons, including patriotism, excitement or a desire to combat slavery. Instead, he claims, the decision of sailors to join was a mixture of practical motivations including guaranteed employment, regular wages, and a chance for prize money. ${ }^{50}$ Both Anderson and Johnson may have been unemployed when they enlisted and Johnson's one year enlistment was, for 1861, uncommon. Most sailors were enlisting for three years. Before the year ended, another sixteen black British North Americans had also enlisted. Of these men, most had selected to serve three years but three men signed on just for one year while two chose a two year term.

Whatever their motivation, the eighteen black British North Americans who entered the Union navy in 1861 differed significantly in their level of skills from the average American naval recruit. Slightly more than half of the Maritime and Canadian sailors were rated as ordinary seamen or higher at a time when seventy-eight percent of new American recruits and eighty percent of the black American recruits were assessed to have "absolutely no skill or experience in things nautical." 51 As a result of their hard earned skills, many of the black Maritimers who joined in the first year of the war were assigned to the existing frigates and sloops of war. Some were placed in ships such as the USS Hartford and USS Brooklyn, but others found berths in the newly expanding navy. David Campbell, a sea cook from Halifax, served his enlistment on the USS Vanderbilt, a two mast, side wheel transatlantic passenger ship given to the government by Commodore Vanderbilt in 1861. Because the Vanderbilt's role was to hunt Confederate commerce raiders, Campbell would see places such as Rio de Janeiro, Brazil, Port Louis, Mauritius, Cape Town, South Africa, Halifax and the West Indies. ${ }^{52}$ By contrast, Berry Chever, an experienced seaman from Halifax, served much of his enlistment on the USS General Bragg, a river gunboat patrolling the Mississippi. ${ }^{53}$ He might not have

49 Many of these men may have been what W. Jeffrey Bolster has called "transient" seamen sailors who signed on for one or two terms because of unemployment on land or a chance for a little adventure. Bolster suggests, and the occupational listings for the recruits confirm, that many of these sailors were familiar with a range of occupations on both land and sea. W. Jeffrey Bolster, Black Jacks: African American Seamen in the Age of Sail (Cambridge, 1997), 178-79.

50 Bennett, Union Jacks, 19.

51 Bennett, Union Jacks, 28.

52 Official Records of the Union and Confederate Navies in the War of the Rebellion (hereafter cited as $O R N$ ), 31 vols. (Washington, 1894-1927) ser. 1, 2: 417, 467-8, 567-71. 
considered himself as fortunate as Campbell for Chever's ports of call included Helena, Arkansas, Greenville, Mississippi, and Natchez-Under-The-Hill.

Most of the black sailors from the British colonies who joined the Union navy did so by presenting themselves at naval recruiting stations called "rendezvous" set up in the major seaports in the northeast. ${ }^{54}$ Usually located in the port areas where sailors lived, drank and whored, and regular citizens avoided, rendezvous often employed recruiting agents or "runners" as well as local boarding house operators to locate potential recruits and to encourage them to enlist. The runners, who received three dollars for every acceptable sailor that they brought in, were not heavily weighted with scruples. Their activities frequently scandalized middle-class citizens. Local businessmen in the lower east side of Manhattan were among the many who protested at the behavior of the recruiters. "There is hardly a day that passes, that the most corrupt and outrageous means are used by these runners to decoy the citizens into the U. S. Navy, and when expostulated with, they are very insulting." ${ }^{55}$ No doubt, some black British North Americans who ended up in the federal navy may have been plied with alcohol and promises of prize money, lied to about their terms of enlistment, or, or in extreme cases, even "shanghaied" or kidnapped. Nineteenth century port towns were notorious for their "crimping" establishments. At best these men were sailor-brokers or agents who matched demand with supply. At worst they were "bold, brutal, and unrestrained" in their manipulation of sailors. ${ }^{56}$ Canadian and Maritime sailors may have been preyed on by recruiters in the United States just as they were in Quebec City, Halifax and Saint John, but the stories of young men in the British colonies being forcibly removed from their homes, while sensational, are based on limited cases, judging by the enlistment records of the black sailors.

In September 1864, nine sailors sent a letter to the British consul in Boston. They claimed that they had been made drunk in boarding houses in Quebec and persuaded to ship aboard a vessel there. They claimed that they had "been sold at Lebanon, New York, for bounty money." They were bitter that they had received only two hundred dollars while the perpetrators had got one thousand. ${ }^{57}$ In another case, it was alleged that men from the Buffalo Rendezvous crossed over to Niagara Falls, drugged young men, hauled them back to the naval officers at the rendezvous who immediately enrolled them and put them on board the USS Michigan, a side wheel

54 Hundreds of the new recruits, along with sailors from vessels undergoing long-term repairs, would be quartered in receiving ships, old and obsolete sailing ships before they were reshipped to their new assignments. Browning, From Cape Charles to Cape Fear, 200-1.

55 Bennett, Union Jacks, 2-3.

56 Judith Fingard describes in detail how crimps worked in Quebec, Halifax and Saint John. Fingard, Jack in Port, 5, 194-241.

57 William F. Raney, "Recruiting and Crimping in Canada for the Northern Forces, 1861-1865," Mississippi Valley Historical Review X (June 1923): 28. 
gunboat. $^{58}$ When the men woke up, they were U.S. sailors. ${ }^{59}$ In Digby, Nova Scotia, a local youth was reportedly drugged and placed aboard a schooner for Boston and only saved by the prompt action of Digby citizens. ${ }^{60}$ In fact, only one black sailor from Canada West, John Ryde, a thirty-five year old cook, enlisted at the Buffalo Rendezvous during the entire war and while many others enlisted in Boston, a line of drugged bodies being carried off vessels in the harbor would have drawn attention. ${ }^{61}$

Moreover, few British North American sailors signed on in border towns. Three quarters of all black Maritime sailors enlisted at either New York or Boston, and while most of the remainder signed on at cities such as Philadelphia, Baltimore and New Bedford, there were a few exceptions. John Lewis from Nova Scotia enlisted at Acapulco, Mexico, and served out his term on a Pacific Squadron store ship, the USS Farallones. Jacob Tucker, an experienced sailor from Halifax, enlisted in the US Navy for one year at Antwerp, Holland. By contrast, almost three quarters of the recruits from the Canadas (160 out of 222) enlisted in New York while less than ten percent (19 out of 222) joined in Boston. More men joined in Brooklyn (24) than in Boston while others enlisted at rendezvous in Cairo, Cincinnati, Chicago, and other western cities. The surge of naval enlistment in late 1863 and 1864 was possible, in part, because of the deskilling associated with the change from sail to steam. The need for skilled men who could reef sails in heavy weather declined and the need for untrained manual labor grew. By 1863 the navy hired civilian recruiters to find the specific labor it needed. The civilians, some runners and some crimps, got "three dollars for each seaman or ordinary seaman but ten dollars for each landsman or coal heaver" that they brought in. ${ }^{62}$

When naval recruiters, runners, and crimps were trying to persuade young men to choose the navy rather than the army, the major incentive that they could hold out to the eager or the gullible was prize money. All Confederate warships and any merchant vessel attempting to evade the blockade of Southern ports were subject to seizure by Union vessels as legitimate prizes of war. The Prize Law, established by the U.S. Navy in 1798, set out the rules for the capture of ships violating a legal blockade and the resulting auction and sale of the confiscated vessels and cargos. ${ }^{63}$ After deducting court costs,

58 The USS Michigan, the first iron hulled ship in the US navy, spent all of her service on the Great Lakes. During the war one of her duties was to ferry new recruits between Buffalo and western Lake Erie ports on their way to Cairo, Illinois, and the Union vessels on the Mississippi River.

59 Adam Mayers, "Stolen Soldiers," Civil War Times Illustrated 34 (June 1995): 56.

60 Marquis, In Armageddon's Shadow, 98.

61 David Valuska records Adams Willis of "Canada" as having enlisted in Buffalo in late July 1864 although Willis is not in the Civil War Sailors Project data bank. Valuska, The African American in the Union Navy: 1861-1865, 313.

62 Ramold, Slaves, Sailors, Citizens, 65-5.

63 For a case study that illustrates the complexities and conflicts that the settlement of a prize could generate see Frederick C. Leiner's "The Squadron Commander's Share: Decatur vs Chew and the Prize Money for the Chesapeake's First War of 1812 Cruise," Journal of Military History LXXIII (January 2009): 69-82. 
which could vary significantly in different jurisdictions, the Navy Department passed on half of the prize money to be distributed among the crew of the vessels taking part in the capture. $^{64}$ All federal vessels within signal distance of the ship making the capture received a share. In practice it meant that all Union warships within six miles received part of the prize money. The commander of the blockading squadron received five percent while the captain of the capturing warship got ten percent. The remaining thirtyfive percent was divided among the crew or crews according to their rating. ${ }^{65}$

The potential reward for members of a lucky crew off a busy blockade running port could be significant. William Brown of Nova Scotia was one of the lucky sailors. He enlisted in Brooklyn on 8 August 1864 and had joined the crew of the USS Eolus, a small side wheel steamer built as a merchant vessel in 1864 with a complement of just over fifty men. Because of her good speed and low silhouette, she was used for close in work on the Wilmington, North Carolina, blockade. Two months after Brown joined the crew, the vessel intercepted the side-wheel steamer Hope running the blockade with a cargo of machinery and, after a sixty-five mile chase, captured her. The amount of prize money for distribution was ruled to be $\$ 263,296.83$ and each seaman on the ship got just over $\$ 1000$. Just nine days later, the Eolus, along with USS Calypso, captured another prize, Lady Sterling and this time the prize money to be shared amounted to $\$ 494,891.29$. Brown may have seen the irony of a Maritime sailor getting wealthy by the capture of a blockade runner based out of Halifax. ${ }^{66}$ Brown, however, was unusually fortunate. The four black sailors from British North America who crewed on the screw frigate, USS San Jacinto, a particularly successful prize winner with a complement of 278 , reflected a more common experience among blockaders. John W. Price of Nova Scotia joined the crew in December 1863, thus missing the capture and prize money from the steamer Alabama worth $\$ 120,951 .{ }^{67}$ By the time that Price had joined the San Jacinto, legitimate prizes were fewer and chases more frequently resulted in the destruction rather than capture of enemy vessels. ${ }^{6}$ Price was, however, eligible for prize money from the capture of Edwards $(\$ 2,139)$, Magnolia $(\$ 430)$, Roebuck $(\$ 8,096)$ and Lealtad $(\$ 38,880)$. By the time that William B. Johnson from Nova Scotia, John Backus of Canada West, and Elijah Nellis of Saint John, New Brunswick joined the crew in October and November 1864, the frigate was finishing repairs in Portsmouth, New Hampshire. When the San Jacinto returned to the Gulf blockade, legitimate prizes were scarce and one of

64 The court costs to process the alleged prizes were almost three times as high in New York as they were in Boston. Browning, From Cape Charles to Cape Fear, 262.

65 Hoogenboom, Gustavus Vasa Fox, 99.

66 The Lady Sterling was one of the many ships that cleared Halifax fully loaded theoretically bound for Nassau or Bermuda only to dash for Wilmington. ORN, ser.1, 10: 469, 476; 12: 529, 543; Browning, From Cape Charles to Cape Fear, 263; David D. Porter, Naval History of the Civil War (New York, 1886), 838, 839; David G. Surdam, Northern Naval Superiority and the Economics of the American Civil War (Columbia, 2001), 85.

67 ORN, ser. 1, 17: 550-54; Porter, Naval History of the Civil War, 837.

68 By August 1864, Secretary Welles was forcefully reminding his admirals that sinking and destroying of blockade runners took precedent over attempts to take them as prizes. ORN, ser. 1, 10:402-03. 
the few prizes credited to the frigate in 1864 was valued at only $\$ 7.08$. While the four sailors did not share equally in the prize money, they did share the hardships and danger when the San Jacinto struck a reef and foundered near Grand Abaco Island, Bahamas, on the first day of $1865 .{ }^{69}$

Black sailors from the Maritimes and the Canadas may have enlisted in the Union navy with the hope of getting rich from prize money, but most would have been disappointed. Sailors not on warships in American waters, not involved in one of the blockades, or working on the many auxiliary vessels that served the fleet had little chance of seeing prize money. Some ships were too old, too slow, or stationed in places where they would never encounter a potential prize. Moreover, many of the British North American sailors had enlisted late in the war, when fewer prizes were taken. ${ }^{70}$ Of the more than one hundred sixty vessels on which black sailors from British North America served, fewer than a third had ever taken a prize. Even ships on some of the active blockading stations had little hope of ever seeing a blockade runner, much less catching one. William Keeler of the USS Florida felt sorry for the ships stationed along parts of the Gulf coast. "As I saw the solitary blockaders watching this dreary stretch of naked sand, cut off from the world for such long periods of time, not even blockade runners to chase or rebel batteries to watch to relieve the monotony of their life \& too far apart for an occasional visit to each other, I thank that my lot has been with the N.A.B. [North Atlantic Blocking] Squadron."71 Of course, even sailors who had little chance of getting prize money clung to that faint hope because they had few other financial resources.

Although black British North American sailors differed from their American counterparts in many ways, they shared a similar hard-scrabble manual-labor background. Northern sailors overwhelmingly came out of poor working-class conditions which helped feed popular attitudes that sailors ranked among "the lowest class of humanity." ${ }^{, 72}$ As Table 2 indicates, black sailors from British North America also came out of a working-class background, although there were some significant variations.

The recruits' occupational self-identification can be fitted into six broad categories. Fifty-two claimed to be mariners or seamen and, among the Maritimers, only a few of recruits, all under twenty-one years, were not subsequently rated as such. James Sullivan, a thirty-year-old mariner from Nova Scotia who enlisted in October 1864, was

69 The captain of the vessel, Richard W. Meade, was subsequently court martialed for negligence. ORN, ser.1, 17: 790-1, 793-5.

70 In October 1864, however, sailors in the Mississippi Squadron benefited from Admiral David Porter's general order that all enemy property, in particular cotton, could be seized as legitimate prize of war and sent to Cairo for adjudication. The potential prize money was immense. In one case, adjudicated in early 1865 , more than $\$ 450,000$ was distributed to the crews of twenty-one vessels. Porter, Naval History of the Civil War, 835; Symonds, Lincoln and His Admirals, 284.

71 Robert W. Daly, ed., Aboard the USS Florida, 1863-65:The Letters of Acting Paymaster William Frederick Keeler, U. S. Navy to His Wife, Anna (Annapolis, 1964), 210. 
the highest rated of all of the recruits, signing on as boatswain's mate. ${ }^{73}$ The navy was a little more skeptical of some of the men claiming to be seamen, boatmen, or watermen who came from Canada West. Only twelve of the twenty-three volunteers from that colony were rated as ordinary or able seamen. ${ }^{74}$ Some recruits were too young to have had much experience on the water or had listed "mariner" as one of two occupations. In addition, the navy may have been trying to save money by "under rating" recruits while recruiting officers in the eastern ports may not have seen fresh-water sailors as real mariners. Nevertheless, the number of young black men in Canada West who claimed a maritime occupation speaks to how important river and lake shipping was to the province.

\begin{tabular}{|l|c|c|c|c|c|c|c|}
\hline & Mariner & Laborer & Farmer & Tradesman & Service & $\begin{array}{l}\text { Nonel } \\
\text { Blank }\end{array}$ & Total \\
\hline Canada West & $23(12)^{*}$ & 36 & $20(2)$ & $32(3)$ & $73(4)$ & $30(2)$ & $214^{* *}$ \\
\hline Canada East & - & 4 & - & - & 3 & - & 7 \\
\hline Nova Scotia & $19(16)$ & 5 & - & $10(2)$ & $21(4)$ & $19(13)$ & 74 \\
\hline New Brunswick & $9(8)$ & 3 & - & $7(2)$ & $20(3)$ & $10(5)$ & 49 \\
\hline PEI & $1(1)$ & - & - & - & 1 & 1 & 3 \\
\hline Total & $52(37)$ & 48 & $20(2)$ & $49(7)$ & $118(11)$ & $60(20)$ & $347^{*}$ \\
\hline
\end{tabular}

\section{Table 2: Occupation of Black British North American Sailors}

* The number in parenthesis indicated the men in each occupational category who were rated above landsmen.

** Not included in the table of occupations is George Mallory who enlisted in Napoleon, Arizona, on 21 February 1863 for one year as a second class boy. He gave his place of birth as Toronto, Canada, his age as thirty-five years, and his occupation as "slave."

Almost as many recruits claimed to have worked as laborers as claimed to have been sailors, and they were almost all rated as landsmen at the rendezvous. The only farmers enlisting from British North America came from Canada West and while most of these men were rated as landsmen, two of the farmers were rated as seamen, indicating that they had previous experience at sea. A significant number of recruits from all of the colonies gave their occupations as tradesmen - shoemakers, tanners, carpenters, blacksmiths, barbers, and painters, etc. - and slightly more than fifteen percent received a seaman's rating. The largest number of recruits had worked in various service occupations, made up primarily of cooks, waiters, and stewards but only a limited number were rated as such. Cooks and stewards earned considerably more than seamen (twenty-five or thirty dollars per month) and they were technically petty officers although

73 Sullivan served all of his two year enlistment on the USS Monadnock, a twin-turret monitor commissioned in October 1864. He sailed with her when she left Philadelphia for California by way of the Straits of Magellan. Hoogenboom, Gustavus Vasa Fox of the Union Navy, 27071; http://www.history.navy.mil/danfs/m13/monadnock-i.htm

74 Joseph P. Reidy has argued that the navy frequently discounted black mariners' skills and used the case of James Forten Dunbar, the nephew of a prominent sail maker in Philadelphia as illustration. Reidy, "Black Men in Blue during the Civil War," 160. 
some functioned more as personal servants. ${ }^{75}$ Many cooks and stewards managed shipboard accounts, purchasing small order supplies and assisting the paymaster with monthly stipends. ${ }^{76}$

Another sixty of the black volunteers from British North America either listed their occupation as "none" or did not answer the question. These men were most likely unemployed at the time that they enlisted. It was clear, however, that many men who enlisted had worked in multiple occupations. Thomas Bryant of Quebec who listed his occupation as "barber/ pistol maker" or Hosea J. Easton or Canada who was a "waiter/ shade painter" were among numerous recruits who listed two occupations. Moreover, twenty men who claimed a non-maritime occupation were subsequently rated by recruiting officers as ordinary seamen or higher, indicating that they too had seafaring experience. Not surprisingly, men from the Maritime colonies with multiple occupations were more likely to have spent time on the water than recruits from Canada West or Canada East. Not only did more of the black recruits from New Brunswick and Nova Scotia claim to be seamen (thirty percent) than did those from Canada West (twelve percent) but even the men giving no occupation were also more likely to have been sailors. Two thirds of the black Maritimes with no job were subsequently rated as seamen at the rendezvous while only two of the thirty Canadians claiming no occupation were rated above landsman.

The decisions made by young black men from the British colonies to enlist in the navy rather than the army put them into a very different military and social culture. When the young men from the black community at Buxton, Canada West, went off in a group to join a Michigan infantry regiment, they were typical of many army recruits, both black and white. New recruits often came from the same community and their service together reinforced the bonds to home. For many men from British North America, this meant that they could serve with comrades from the same province as themselves and frequently with friends or kin. Moreover, they frequently shared an ideological commitment to save the Union, to fight against the institution of slavery, and to preserve a certain way of life. For foreign volunteers in the army, long service in one or two regions of the United States conditioned some of these men to see the United States as a potential future home. As a result, soldiers frequently served through the war surrounded by old friends, acquaintances and even relatives while they began to develop new ties to the communities in which they served. By contrast, recent studies of Civil War sailors have found little romanticism or altruistic motives among the naval recruits. For Michael J. Bennett; "[t]he typical Union sailor was a hard, pragmatic, and cynical man who bore little patience for patriotism, reform, and religion. He drank too much, fought too much, and prayed too little."77 For other historians, this depiction of sailors as hard men, cut off from the bulk of society, seems a little too harsh and too close to the stereotypical depiction of sailors as drunken and violent misfits, in conflict with genteel society. Eric W. Sager, by contrast, presents the sailors' essential character as a workingman's 
resistance to a difficult world. To their struggles against arbitrary authority and hostile elements, the mid-nineteenth century sailor "brought the capacity for adaptation and survival of men who were literate, migratory, self-reliant, and tenacious in defense of assumed rights. They were not brutalized or enfeebled by their workplace," but found their strength through common cause. ${ }^{78}$

Ironically perhaps, for men who would form tight bounds with their shipmates, recruits entered the navy, as they generally joined merchant ships, overwhelmingly as individuals. $^{79}$ A few sailors, such as the two Prince Edward Island sailors, John H. Thompson and Charles H. Trust, or Philip Bushlaw and Edward Johnson from New Brunswick, may have enlisted together, served in the same vessel, and left the navy together but they were the exceptions. ${ }^{80}$ More frequently, black sailors joined independently and were then dispersed throughout the fleet as the navy needed them. These recruits were seldom able to serve on ships with black sailors that they had known before the war or who had come from their home colony, let alone their home town. Spread throughout the fleet, and confined to one ship for varying lengths of time, a seaman's sense of belonging and identification was more to a ship's complement than to a region, state or country. When that the ship was decommissioned or the sailor's term of enlistment expired, that particular sense of a community ended as well. Not surprisingly, the black sailors from British North America saw service in virtually every part of the Civil War navy, serving in more than one hundred and sixty different vessels. Unlike soldiers who normally served throughout the war in just one regiment, the "average" sailor was more likely to serve on multiple ships during the war. Some seamen, such as Thomas B. Jackson from "Canada" who enlisted 12 August 1864 for three years, might serve their entire enlistment on one ship, but that was not the norm. More common was the experience of Isaac Layton of Montreal who served on five different ships or George Powers from Saint John, New Brunswick, who served on six.

Because they did not enter the navy as a collective group, few black British North American sailors could expect to serve alongside other black men from their home province although they would have found many more white sailors from British North America serving on the Union vessels. Indeed, only four ships in the entire Union navy ever had more than five black British North Americans on their roster during the war. Almost forty black British North Americans served, generally for brief periods, on the USS Minnesota but that was a unique case. While a handful of recruits from Nova Scotia, most of whom were rated seamen, joined the frigate in the first part of the war and served for extended period, most of Minnesota's foreign black recruits, all of whom were

78 Eric W. Sager, Seafaring Labour: The Merchant Marine of Atlantic Canada, 1820-1914 (Montreal, 1989), 3, 199.

79 The obvious exception occurred when black soldiers were transferred from the U. S. Army to the navy in 1864 .

80 Thompson and Trust were both in their early twenties when they enlisted at Portsmouth, New Hampshire on 9 September 1864 for three years. They would both serve on the USS Mohongo, a side wheel gunboat. Bushlaw and Johnson were born in Saint John and they joined together at New York on 22 December 1864 for a similar two year term. They served out their enlistment together on the USS Spirea. 
landsmen or boys, came from Canada West and enlisted in July and August 1864, as enlistment in the navy soared. For them, the Minnesota, stationed at Hampton Roads, acted as a receiving ship and they were quickly moved from the frigate to other vessels, some men staying for only a few days or weeks. ${ }^{81}$ Indeed, only four men, Samuel Fuller, James Monroe, Reuben Randall, and Henry Staats (or Stoats), were still on the warship a few months later when she took part in the attack on Fort Fisher, North Carolina, on 1315 January $1865{ }^{82}$ They were part of less than two dozen black sailors among the ship's crew of 562. ${ }^{83}$ They did, however, have white British North Americans around them with whom they may have formed a common bond. Forty-two of the white sailors on the frigate were from Canada West, Nova Scotia, and New Brunswick. ${ }^{84}$

One ship, USS William Badger, an old whaling ship that the navy had purchased at the start of the war, may have been the only ship in the Union navy with a majority of its complement made up of black sailors from a British colony. From the summer of 1864 to the fall of 1865, fifteen black sailors, thirteen from Canada West, one from Nova Scotia and one from New Brunswick were stationed on the Badger, at a period that the vessel was used as a "supply hulk" at Beaufort, North Carolina. ${ }^{85}$ The Badger, and two other old vessels, the USS Arletta and the USS Release, were demasted and lashed together as a floating storehouse. ${ }^{86}$ It must have been an unpleasant posting. Described as "totally unfit for the preservation of government property," the vessel "was rotten and leaked and was infested with rats that destroyed the stores." 87 A ship the size of the Badger, 334 tons, would normally have a crew of about two dozen to serve it so the British North American seamen would have been the largest group on the ship. ${ }^{88}$ In addition, two other Canadians, Aaron Jordan and Charles Vail, plus Levine T. Baynard from New Brunswick, served on the Arletta.

The only other naval vessel with more than five black sailors from the British colonies was the USS Potomac, an ageing frigate built in 1822. The vessel, with a

81 ORN, ser. 1, 10: 244, 326.

82 The attack cost the ship thirty-three crewmen but it is not clear how many, if any, were from British North America. Chris E. Fonvielle, Jr., The Wilmington Campaign: Last Rays of Departing Hope (Mechanicsburg, 1997), 258.

83 Barbara Brooks Tomblin, Bluejackets and Contrabands: African Americans and the Union Navy (Lexington, 2009), 258.

84 Two of these sailors, William Martin of Nova Scotia and Francis Peters from Montreal, may well have been black sailors who were missed by the Civil War Sailors Project. Both men had their eyes, hair and complexion described in the description books as "black" or "dark," a common listing for African Americans in the Civil War description books. Tomblin, Bluejackets and Contrabands, 329-30; www.tfoenander.com/minnesota.htm.

It is entirely possible that the entire crew of the Badger were black since black sailors were often assigned to similar storeships to provide the manual labor required. ORN, ser. 1, 11: 193, 400.

86 Ramold, Slaves, Sailors, Citizens, 96.

87 Browning, From Cape Charles to Cape Fear, 176.

88 Silverstone, Civil War Navies, 104. 
complement of 480 officers and men, served a wide range of tasks. For part of the war, its function was to escort convoys of "California steamers" on the route "from New York to Aspinwall [Panama] and back." ${ }^{89}$ Subsequently, the Potomac served as a stores ship for the Gulf Blockading Squadron and then as a receiving ship. Of the twelve black British North Americans who served on the frigate, the majority did so only after the start of 1866 when the USS Potomac was stationed in the Pensacola Naval Yards as a receiving ship. Only two had joined the ship in 1864, Aaron M. Brown and Thomas B. Jackson both from Canada West, and they arrived months after the Potomac had received credit for its last prize, the schooner Champion. ${ }^{90}$

While black Canadian and Maritime sailors who joined the Union navy could be found in virtually every theatre of the war, the majority of them served either in the blockading squadrons in the Atlantic, concentrated at Wilmington and Charleston, or along the Gulf coast. Far fewer served with the Mississippi Squadron, the "brown water" navy that patrolled the inland waterways in support of the Union army. Men who thought that service in one of the blockading squadrons would guarantee excitement and prize money were soon disappointed. Even off an active blockade running port such as Wilmington, boredom dominated. "It is to be one dull monotonous round, day after day, week after week, yes \& month after Month... [N]o papers, no letters, "no nothing," lamented William Keeler on the Florida. "Up \& down the coast just within sight are others of the fleet going through the same dull routine of duty as ourselves."91 Ships on the blockade of Charleston found life just as tedious. "Nothing broke the monotony," recorded Commander John Marchand of the USS James Adger, "and I became heartsick and tired." 92

Given their divergent service, collectively the black colonial sailors were involved in many of the key events of the maritime war. In the last great naval campaign of the war, the assault on Fort Fisher guarding the last major blockade running port of the Confederacy, black British North Americans served on two of the ironclads, eight of the frigates and sloops of war, three of the double-ended side-paddle gunboats, four of the screw gunboats and more than a dozen of the auxiliary craft. Although some of these ships were repeatedly hit by Confederate fire, the damage to Union vessels was generally limited. The USS Mackinaw's port boiler was ruptured by a Confederate shell and ten men were scalded but neither George Douglas from Hamilton, Canada West nor John A. Jarvis of Nova Scotia who were members of the crew were injured. ${ }^{93}$ On the other

89 Aspinwall, the name given by the American émigré community to the town of Colon, was the eastern terminus of the Panama Railroad. ORN, ser. 1, 3: 217.

90 Even in the summer of 1864, crew members from the Potomac were being transferred to more efficient steam powered vessels. ORN, ser. 1, 21: 171; Silverstone, Civil War Navies, 96; Porter, The Naval History of the Civil War, 835.

91 Daly, Aboard the USS Florida, 1863-65,

92 Craig L. Symonds, ed., Charleston Blockade: The Journals of John B. Marchand, U.S. Navy, 1861-1862 (Newport, 1976), 75.

93 When the Mackinaw's captain signaled that he was in a disabled and defenseless condition, Admiral David Porter responded, "Remain where you are and fight." John W. Grattan, Under the Blue Pennant or Notes of a Naval Officer, 1863-1865, Robert J. Schneller, ed. 
warships, the sailors had more to fear from their own guns than from Confederate fire. Defective iron cast guns burst on the USS Juniata, Mackinaw and Quaker City, leaving dozens of sailors injured. On the Juniata alone, eighteen officers and crew were killed or wounded by the bursting of a 100-pound Parrott rifle. ${ }^{94}$

Some sailors had more adventuresome, or at least more dangerous, service than the sailors who crewed supply vessels or blockading ships. John W. Mitchell was a twenty-nine year old sailor from Saint John, New Brunswick when he enlisted in Boston in March 1862. In October, he was mustered into the crew of the USS Cairo, one of the first river ironclads, becoming one of the few black Maritimes to serve in the Mississippi Squadron. While he was the only black British North American in the crew of 159 men, there were seven other white sailors who had been born in "Canada." $"$ On 12 December 1862, while clearing mines in preparation for an attack on Haines Bluff, Mississippi, the vessel struck a torpedo, or mine, which was exploded by Confederates hiding on shore. ${ }^{96}$ The ironclad became the first armored warship claimed to be destroyed by an electrically detonated mine. ${ }^{97}$ Mitchell survived the explosion and was transferred to the USS Rattler, a "tinclad" river gunboat. He was serving on the Rattler when its commander, Acting Master Daniel W. Glenny, tried, unsuccessfully, to deliver the ship and her crew into Confederate hands for cash, one hundred bales of cotton, and the command of a blockade runner. ${ }^{98}$ Then, only a few months after avoiding Confederate capture, the vessel was driven ashore in a heavy gale near Grand Gulf, Mississippi, holed on a snag and sank. Mitchell survived, one of a handful of sailors to survive two shipwrecks during the war.

Another "brown water" sailor from Canada West was not as fortunate. William Johnson, a twenty-six year old experienced mariner who had enlisted at Boston in July 1864, joined his new ship, USS Massasoit, a Sassacus class gunboat performing picket duty on the James River in Virginia. Five months later, the gunboat took part in the 24 January 1865 duel with Confederate batteries at Howlett's House and took several hits. ${ }^{99}$

\section{(New York, 1999), 153.}

There is no indication if any black British North Americans were among the injured. The records give the numbers of injured but not their names. Fonvielle, The Wilmington Campaign, 136-7; Grattan, Under the Blue Pennant, 152.

David F. Riggs, "Sailors of the U.S.S. Cairo: Anatomy of a Gunboat Crew," Civil War History XXVIII (September 1982): 270.

97 Although Joiner believes that the explosion was detonated electrically, Timothy S. Wolters, in an extensive article tracing the early advocates of electric torpedoes (or mines), argues that the first warship sunk by an electric torpedo was the USS Commodore Jones in May 1864 in the James River. Wolters, however, focuses most of his attention on actions on the eastern seaboard. Joiner, Mr. Lincoln's Brown Water Navy, 101; Timothy S. Wolters, "Electric Torpedoes in the Confederacy: Reconciling Conflicting Histories," Journal of Military History LXXII (July 2008): 756. John D. Milligan, Gunboats Down the Mississippi (Annapolis, 1965), 104-5; Valle, Rocks and Shoals, 165; Bennett, Union Jacks, 97. 
Johnson was wounded by shell fragments. After a long convalescence at the Norfolk Naval Hospital, he was discharged from the navy for reasons of disability. ${ }^{100}$

While most of the black British North American sailors spent all of the war in American waters, a few served on ships tasked with tracking down Confederate raiders in the North or South Atlantic or intercepting ships carrying slaves from Africa. William H. Thomas of Saint John, New Brunswick, was one of the first sailors to enlist, volunteering in December 1861. He joined the newly refurbished USS Onward, a sailing cruiser that was ordered first to help in the Charleston blockade. As a sailing ship, her usefulness in the blockade was limited although she did manage to destroy by driving ashore two small schooners, the Chase and Sarah. ${ }^{101}$ The Onward was then ordered to join in the hunt for Confederate commerce raiders operating in the South Atlantic. ${ }^{102}$ In March 1863, the Onward, along with the USS Mohican, blockaded two Confederate supply vessels, CSS Agrippa and CSS Castor, in Bahia, Brazil, forcing them to sell the supplies that they carried for the Confederate raiders, CSS Alabama and CSS Georgia. As a result of the actions of the Onward and Mohican, the effectiveness of the two Confederate raiders was greatly reduced. ${ }^{103}$

Jacob Tucker of Halifax, by contrast, served his one year enlistment onboard the USS Niagara, a screw frigate then attached to the European Squadron. Tucker, who was already in Europe, joined the frigate when it stopped at Antwerp, Holland, while searching for the Confederate cruisers built in British and French ship yards. Too late to join the USS Kearsarge in the destruction of the CSS Alabama, the Niagara was frustrated in its attempts to intercept the ironclad ram, CSS Stonewall, as it left Ferrol, Spain. ${ }^{104}$ February 1865 , as the frigate waited for the Confederate warship to leave port, was a stressful time for the crew and a number of sailors deserted. One black crewman recorded the mood of the ship in his diary. "All of the talk is of the Ra[m]. We expect that she is an ugly customer to handle, but we will not be dismayed." 105 Fortunately for Tucker and his fellow crewmembers, the Stonewall managed to slip out of port unnoticed and the Niagara never faced the Confederate ironclad in battle. Despite arguments that sailors were little motivated by ideology and despite the fact that Tucker's enlistment may have been opportunistic, he was one of a number of black seamen who contributed money to the Anglo-African, a black paper in Washington, to be used to aid the

100 Ramold, Slaves, Sailors, Citizens, 129.

101 Symonds, The Charleston Blockade, 150.

102 ORN, ser. 1, 3: 195, 424-5.

103 As late as May, 1864, the captain of the CSS Alabama, Raphael Semmes, was still hoping that Agrippa would arrive, although he admitted that he feared "some disaster has befallen her." ORN, ser. 1, 2: 743; Civil War Naval Chronology (Washington, 1971), VI-190; Silverstone, Civil War Navies, 103.

104 The USS Niagara and its consort, the USS Sacramento, wanted to engage the ram when the weather was blowing and the seas rough. A smooth sea, they felt, gave too great an advantage to the armored Confederate cruiser.

105 William B. Gould IV, Diary of a Contraband: The Civil War Passage of a Black Sailor (Stanford, 2002), 220, 225. 
freedmen. ${ }^{106}$

Although the resources of the U.S. Navy were stretched to their limit during the war, the combination of the Lyons-Seward Treaty of 1862 and a separate agreement signed with Denmark pledged the Union navy to become more active in the suppression of the international slave trade. Twenty-four naval vessels "were designated as available for suppression of African slave trade." 107 A dozen black British North Americans served on seven of the designated ships. ${ }^{108}$ Although it is not clear how many of them would have seen any action against ships engaged in the slave trade, at least one black Nova Scotian, Henry Forman from Halifax, saw service in the West Indies. He joined the USS Powhatan in October 1864 at Cape Haytien (Haitian) in Haiti while the warship, part of a ten vessel squadron, was on patrol in the Caribbean. ${ }^{109}$ Before his one year term was up, however, the Powhatan was back in American waters as part of the assault on Fort Fisher. $^{110}$

How the black sailors were viewed by their white crewmates and the extent to which they faced less animosity than black soldiers has been hotly debated by historians. Because the navy, unlike the army, had allowed black enlistment from the very start of the war, had racially integrated its ships, and had paid black sailors the same wage as white sailors, their treatment by the military seemed, at least to some historians, to have been substantially better than that of white soldiers. The most persuasive argument for a less racist navy is put forth by Steven J. Ramold. In his monograph on African American sailors during the Civil War, he forcefully argues that black sailors were treated, in the context of mid-nineteenth century America, remarkably well. In addition to integrating the crews, "the navy ensured equal pay and benefits, promotion opportunities, standard of living, and health care to its African American sailors, in sharp contrast to the experience of many black soldiers."111 While there were numerous signs of prejudice among individuals in the navy, as an institution there was nothing in the navy's official policies that was racist. By contrast, historians such as Michael J. Bennett have argued that racism was an integral and ever present part of the Union navy. Steeped in racial stereotypes, white sailors rejected contrabands as crewmates while the tensions of an

106 Gould, Diary of a Contraband, 75.

107 Conway W. Henderson, "The Anglo-American Treaty of 1862 in Civil War Diplomacy," Civil War History XV (1969), 308-11; Valuska, The African American in the Union Navy, 68. For Rear Admiral S. F. Du Pont, the twenty-four identified ships were the maximum "which in all possibility can ever be used for the purpose set forth in the treaty." ORN, ser. 1, 14: 229-30.

108 While these ships, including the USS Wabash, USS Paul Jones, USS Powhatan, USS Unadilla, USS Flag, USS South Carolina, USS Flambeau on which black British North Americans served, were to be available to interdict the trade, most of their time was spent in American waters.

109 A. Taylor Milne, "The Lyons-Seward Treaty of 1862," American Historical Review XXXVIII (1933), 515.

110 http://www.hazegray.org/danfs/steamers/powhatan.htm

111 Ramold, Slaves, Sailors, Citizens, 5. 
integrated ship triggered violent confrontations, or "frictions," in which white seamen targeted black sailors. While white soldiers may have used violent language in their objection to black enlistment, Bennett argues, their reactions "to the introduction of slaves into the army were relatively nonviolent." ${ }^{\text {"112 }}$ The very integration of racially mixed crews in confined quarters exacerbated the tensions. Here he agrees with David Valuska that close contact created "an atmosphere conducive to hostility between the races."

However, the arguments about which branch of the service was preferable for black recruits often ignores the complex dynamics of racism and class. While most white Americans, indeed most white North Americans, held various forms of prejudice against people of African descent, those prejudices were never monolithic, consistent or static. Attitudes varied considerably by region and by economic and cultural groups. The greatest prejudice and most overt racism were directed at African Americans who were, or had been, slaves. Some whites justified this bigotry on the basis that the former bondsmen had been "scarred" by the institution of slavery and had not benefited from the attributes of a free Northern society. Samuel Gilbert Webber, the surgeon of the USS Nahant on which two black cooks from Canada West served, captured the prejudice of many whites towards the ex-slaves in a letter to his wife. "Though I do not believe the negro equal to the white or that the african [sic] race will approach the caucasian [sic] in intelligence until after many years of training; yet I do believe them entitled to freedom." Webber conceded, "It may be that after many generations the degradation of slavery, its debasing \& lowering influence will be overcome \& they will rise higher than most expect; but if this ever happens it must be after long training first." ${ }^{113}$ Given such widespread attitudes towards slavery and the ex-slaves, the worst of the racial harassment and the most violent incidents, the very ones cited by Bennett, was overwhelmingly directed at the "contrabands." Edward W. Hammond, a white boatswain of the USS St. Mary, recalled years later the "intense race hatred" directed at the ex-slaves by some of the white sailors. Sailors normally used the evening dog watches to relax on the main deck, but a group of white rowdies made sure that the black sailors would be excluded by throwing gun chocks at any black crewmen who showed his face above deck. Hammond remembered that even he and other white sailors who normally gathered around the steerage hatchway or open deck areas were in danger. Only, he wrote, by "setting down on deck with our backs to the after side of a gun, we were comparatively safe."

By contrast, Northern blacks were generally perceived to be more independent and intelligent, and better fitted to integrate into white communities. It is not clear how individual black British North American sailors were categorized by most white Americans. While they had the advantage of being identified as the beneficiaries of a free democratic

112 Bennett, Union Jacks, 180.

113 Tomblin, Bluejackets and Contrabands, 14.

114 "A Personal Reminiscence by Edward W. Hammond, Boatswain, U.S. Navy, of an Incident on board the U.S. Ship St. Mary's in Valparaiso Harbor 1865" cited in Reidy, "Black Men in Navy Blue," (pp. 4-5 2/8) from file NJ - Discipline and Minor Delinquencies, Subject File, RG 45, NAB. 
society, they were also lumped into the category of "foreign sailors." Four of them served on the USS Florida whose crew was described by an officer of the ship as "a motley collection for a crew - from all parts of the world - England, Ireland, France, Spain, Portugal, Russia, Austria, Poland, Norway, Sweden, have representatives onboard. Besides these we have a Lascar, a Mexican, Sardinian, Italian, one from Maderia [sic], one from Manila, another from Peru \&c." ${ }^{115}$ Moreover, not only was there a racial hierarchy within the maritime culture which benefited the black British North Americans but there was also an equally imported occupational class structure within the navy based on skill, experience, and background. To the extent that all black British North American recruits were freeborn, part of a cultural background different but equal to northern society and had entered the Union navy frequently with extensive maritime training, they would have been perceived very differently from ex-slaves whose presence on board Union ships generated the ugliest signs of racism. Indeed, their separateness was one of their chief characteristics.

Although black British North American sailors in significant numbers had volunteered to serve in the Union navy during the war, they remained, in important ways, apart and distinct from the larger American society or even the African American community. In this light, the views of both the Secretary of the Navy John Branch and historian Michael Bennett seem correct. Very few of the black sailors were bound to United States by the ties referred to by Branch. Instead the black sailors who came south from the British colonies to enlist in the Union were part of a fluid class of maritime workers whose attachments were more to their form of employment than to their specific employer. Enlistment was a hard-nosed decision that they made based on their own best interests and they exercised considerable agency in selecting when to enlist and for what term they would serve. Later, in their post-war lives, most were involved with American society only marginally. Like all men who had served in either the Union army of navy, in the decades after the conflict all the veterans became eligible for Civil War pensions. More than ninety percent of white Union veterans and three-quarters of all African American veterans had at least one successful pension application. ${ }^{116}$ For the black British North Americans who had served in the navy, less than half even applied for a pension. ${ }^{117}$ They had served the Union navy well, but it was only one part of their employment career.

115 Daly, Aboard the USS Florida, 70.

116 Donald R. Shaffer, After the Glory: The Struggles of Black Civil War Veterans (Lawrence, 2004), 122.

117 Although this research remains on-going, the maximum possible number of black British North America sailors who subsequently applied for a Civil War pension was under 47 percent. This was arrived at by checking the 348 names of these veterans against the master list of names compiled for the navy's civil War pension files held in the National Archives in Washington, D.C. Unlike the army, where names can be verified against regimental name lists, the navy did not link names to vessels on which the veterans served. As a result, for common names, such as "Thomas M. Brown," there are sixty-nine possible files and records of the Thomas M. Brown from "Canada" may, or may not, be among these files. Preliminary research suggests that no more than one third of the eligible naval veterans from British North America ever applied. 